\title{
POLITIK LUAR NEGERI INDONESIA DAN MALAYSIA TERHADAP CHINA DI ERA PERANG DINGIN
}

\author{
Nabil Ahmad Fauzi ${ }^{1}$
}

\begin{abstract}
Since the proclamation on the $1^{\text {st }}$ October 1949, the People's Republic of China has gained an important role in international relations after World War II. The success of communism conquered China, has changed the dynamics of competition between the United States and the Soviet Union that lead the Western Bloc and the Eastern Bloc. The situation has forced the newly independent states in this era, like Indonesia and Malaysia, to determine their position. In addition to facing the same international politics pressures, the two countries also have relations in the domestic issues related to China, namely the existence of the local Communist Party and ethnic of "Chinese overseas". The external and domestic factors that ultimately affect the choice of the countries' foreign policy towards China. This article attempts to identify and explore the factors that influence the similarities and differences in Indonesia and Malaysia foreign policy towards China using the approach threat perception, leader perception and domestic legitimacy within the framework of neo-classical realism. This article is expected to provide scientific contributions to understanding the comparison of Indonesia and Malaysia foreign policy towards China.
\end{abstract}

Keywords: Indonesia and Malaysia foreign policy, the existence of China, Cold War era, threat perception, leader perception, domestic legitimacy, neo-classical realism

\section{Pendahuluan}

Kelahiran Republik Rakyat China (RRC) pada 1 Oktober 1949 menjadi salah satu fenomena besar dalam era Perang Dingin serta berdampak pada konstelasi politik internasional yang didominasi persaingan Amerika Serikat (AS) dengan Blok Barat dan Uni Soviet dengan Blok Timur-nya.Artikel ini dimaksudkan untuk memberi gambaran mengenai bagaimana Indonesia dan Malaysia mengambil pilihan-pilihan politik luar negeri terhadap China sejak keduanya meraih kemerdekaan dan kedaulatan sebagai sebuah negara sampai berakhirnya era Perang Dingin. Pilihan untuk melakukan kajian ini didorong oleh adanya dua faktor determinan yang menghubungkan kedua negara dengan China,yakni politik dukungan China kepada Partai Komunis Malaya (PKM) di Malaysia dan Partai Komunis Indonesia (PKI) di Indonesia serta permasalahan terkait eksistensi etnis China Perantauan (China Overseas) di

\footnotetext{
${ }^{1}$ Staf Pengajar prodi Hubungan Internasional, FISIP UPN Veteran Jakarta. Email:nabilisme@gmail.com
} 
kedua Negara.

Berangkat dari asumsi adanya faktor konstelasi politik internasional dan faktor domestik yang mempengaruhi pilihan politik luar negeri sebuah negara, artikel ini akan mengeksplorasi faktor-faktor yang menyebabkan dan mempengaruhi pilihan politik luar negeri kedua negara terhadap China. Pembahasan dalam artikel ini mengacu pada dua tema besar yakni kebijakan politik dan kebijakan ekonomi dalam politik luar negeri kedua negara terhadap China. Kajian ini menggunakan kerangka realisme neo-klasik dengan pendekatan persepsi ancaman, persepsi pimpinan dan legitimasi domestikuntuk mengekplorasi pengaruh situasi domestik dalam politik luar negeri kedua Negara.Adapun pembahasan keseluruhan isu dalam kajian ini menggunakan pendekatan kualitatif dan kronologis untuk mendeskripsikan konteks dan kerangka kajian.

\section{Konsep Realisme Neo-Klasik dalam Politik Luar Negeri}

Proses perumusan politik luar negeri sebuah negara bukanlah sebuah proses tunggal, melainkan melibatkan banyak faktor. William D. Choplin (1992:165) menyatakan ada empat faktor penentu politik luar negeri bagi sebuah negara, yaitu pertama, situasi internasional. Kedua, perilaku para pembuat kebijakan. Ketiga, kondisi ekonomi dan militer. Keempat, politik domestik. Singkatnya, kebijakan politik luar negeri tidak dipengaruhi oleh hanya satu faktor tunggal yang dominan.

Berdasarkan pandangan tersebut, pembahasan artikel ini menggunakan konsep Realisme Neo-Klasik (Neoclassical Realism) yang merupakan pendekatan kontemporer dalam studi strategissebagai opsi lain dari pendekatan Realisme Klasik dan NeoRealisme yang lahir lebih awal. Gideon Rose dalam artikelnya "Neoclassical Realism and Theories of Foreign Policy"(1998: 144-177) menjelaskan bahwa perspektif Realisme NeoKlasik menggabungkan variabel domestik dan variabel struktur internasional.Menurutnya, ruang lingkup dan ambisi dari politik luar negeri suatu negara digerakkan pertama kali, dan secara spesifik, oleh tujuan rasional dari kekuatan negara. Dampak dari kekuatan dalam politik luar negeri bersifat relatif karena tekanan sistemik harus diterjemahkan melalui intervening variable pada setiap unit level.

$$
\text { Kuik Cheng Chwee }
$$
menyebutkan bahwa konsepsi Realisme NeoKlasik lebih luas cakupannya dari konsep Neorealis tentang "international structure" dalam tiga aspek, yakni; pertama, faktor struktural tidak hanya membawa berbagai ancaman dan tantangan, tetapi juga membuka berbagai peluang.. Kedua, faktor struktural dapat mempengaruhi nilai-nilai eksistensial negara yang tidak hanya dalam hal fisik (security), tetapi juga dasar ekonomi (prosperity) dan basis politik (sovereignty and policy maneuverability). Ketiga, faktor struktural tidak hanya berasal dari perubahan 
dalam kemampuan relatif great power, tetapi juga perubahan dalam hubungan inter-great power (dari mitra menjadi musuh dan lain sebagainya) dan perubahan dalam kadar komitmen strategis mereka kepada negaranegara sekutu dan mitra. Semua perubahan struktural tersebut, dan ketidakpastian yang terkait di dalamnya, menghadirkan sebuah kombinasi tekanan dan manfaat potensial bagi kondisi eksistensial suatu negara.

Ketiga aspek dalam variabel struktural tersebut jelas memberi dampak pada pilihan politik luar negeri suatu negara, namun bukanlah faktor penentu utama. Terdapat variabel domestik yang harus dianalisis, terutama untuk menjelaskan pertanyaan berikut: mengapa negara yang memiliki variabel struktural yang sama, mengambil pilihan politik luar negeri yang berbeda. Dari perspektif Realisme Neo-Klasik, kondisi struktural hanya merupakan lingkungan eksternal di mana negara memandangnya sebagai sebuah ancaman atau peluang. Variabel domestik-lah yang akan menentukan bagaimana negara akan merespon kedua hal tersebut.

Dalam artikel ini, variabel domestik dilihat dari tiga konsep berikut, yakni; pertama, persepsi pemimpin. Menurut K.J Holsti(1998:138), tindakan suatu negara sangat terkait dengan cara pandang (persepsi) pemimpin Negara, di mana persepsi tersebut akan menjadi standar dalam mengartikulasikan setiap situasi yang dihadapi, baik peluang ataupun ancaman. Sedangkan Robert Jervis (1976) menyatakan ada 3 faktor untuk melihat persepsi, yakni;faktor lingkungan internasional, situasi domestik dan birokrasi. Perubahan persepsi dapat terjadi ketika jika terdapat pengetahuan baru yang merubah keyakinan dan nilai (Walter S. Jones, 1988:276).Singkatnya, persepsi pemimpin negara menjadi faktor penting yang berpengaruh besar terhadap pengambilan kebijakan suatu negara.

Persepsi pemimpinbanyak dipengaruhi olehwujudnya konsep kedua, yakni persepsi ancaman. Robert Tilman (1987) menyebutkan lima faktor yang mempengaruhi persepsi ancaman sebuah negara, yaitu; 1) Struktur negara, yang melihat kepada dasar pembentukan negara (jenis perjuangan kemerdekaan) dan lainnya. 2) Posisi geopolitik negara dan kawasan. 3) Sejarah negara. 4) Sosio-budaya dan sistem struktur internal masyarakat, dan 5) Dimensi-dimensi ekonomi. Kelima faktor tersebut membentuk persepsi ancaman terhadap negara tertentu kemudian mempengaruhi persepsi pemimpin dalam merumuskan pilihan politik luar negeri.

Ketiga, legitimasi domestik. Konsep ini mengacu pada cara elite negara yang berusaha untuk membenarkan dan mengkonsolidasikan otoritas moral mereka untuk memerintah. Konsep ini berasumsi bahwa;1) negara tidak membuat pilihan politik luar negeri, tetapi elit pemerintahan yang melakukannya(Howard Wriggins, 1909; Edward E. Azar dan Chung-In 
Moon, 1988),2) elit penguasa lebih fokus pada keberlangsungan politik domestiknya dengan mengurangi segala bentuk risiko (keamanan, ekonomi, dan politik) yang mengancam kekuasaannya (Sukhumbhand Paribatra dan Chai-Anan Samudavanija, 1986),3) dasardasar pemerintahan tidak hanya mengacu pada kepatuhan elit dengan norma-norma demokrasi, tetapi juga kemampuan mereka untuk menjamin keamanan dan kohesi internal, pertumbuhan ekonomi, kedaulatan, dan rasionalisasi ideal yang khas dari suatu negara tertentu (Max Weber, 1984; David Beetham, 1991; Muthiah Alagappa, 1995).

Berikut ini merupakan tabel mengenai politik luar negeri Indonesia dan Malaysia terhadap China yang menggunakan kerangka Realisme Neo-Klasik.

Tabel 1

\begin{tabular}{|c|c|c|c|}
\hline $\begin{array}{c}\text { Independent Variable } \\
\text { (Struktur } \\
\text { Internasional) }\end{array}$ & $\begin{array}{c}\text { Intervening Variables } \\
\text { (Faktor Domestik) }\end{array}$ & $\begin{array}{c}\text { Dependent Variable } \\
\text { (Pilihan Politik luar negeri) }\end{array}$ \\
\hline \begin{tabular}{|l|l|l|} 
Perubahan Sistem \\
Kekuatan
\end{tabular} & $\begin{array}{l}\text { Kepentingan } \\
\text { Internasional } \\
\text { Pegitimasi rezim } \\
\text { Persepsi Ancaman }\end{array}$ & $\begin{array}{l}\text { Persamaan dan perbe- } \\
\text { daan politik luar negeri } \\
\text { Indonesia dan Malaysia } \\
\text { terhadap China }\end{array}$ \\
\hline
\end{tabular}




\section{China dan Latar Politik Internasional} Perang Dingin

Eskalasi Perang Dingin semakin memanas seiring dengan diproklamasikannya RRC oleh Mao Zedong. RRC menjadi simbol kemenangan Komunisme terhadap kekuatan Nasionalis yang didukung oleh AS. Keberhasilan Partai Komunis China (PKC) tersebut menjadikannya sebagai kekuatan utama komunisme di Asia sekaligus memberikan tekanan besar kepada AS. Menyikapi hal ini, AS merespon dengan keras, mulai dari menahan pengakuan atas kedaulatan RRC, mendukung eksistensi Republik China pimpinan Chiang Kai Sek yang terpinggirkan di Pulau Taiwan sampai menolak pemberian kursi Dewan Keamanan PBB (DK PBB) kepada RRC (Artikel dalam www.history.com).

China menampilkan politik luar negeri yang agresif manakala mereka terlibat aktif dalam Perang Korea selama 1950-1953. Hal tersebut memberikan pesan kuat bahwa China berpotensi menjadi kekuatan komunis terbesar di Asia (Taufik Adi Susilo, 2009:121).Dalam perkembangannya, China semakin agresif dan independen dalam politik luar negerinya seiring dengan pilihannya untuk keluar dari Komunisme Internasional akibat "pengkhinatan" Uni Soviet yang memilih mengikat perjanjian dengan AS dan Barat mengenai percobaan senjata nuklir pada tahun 1963 (Abdullah Dahana, 2002:60). Situasi ini melahirkan konstelasi baru dalam era Perang Dingin yang disebut sebagai politik segitiga
AS, Uni Soviet dan China.

Melalui politik segitiga ini, AS mengambil kesempatan untuk melakukan pendekatan kepada China sebagai bagian dari upaya meredam pengaruh Uni Soviet melalui Doktrin Nixon yang digagas oleh Presiden Richard Nixon tahun 1969 (Dahana, 2002a:167). Sejak itu, AS mengambil dua kebijakan strategis, yakni mendukung China untuk menduduki kursi anggota tetap Dewan Keamanan PBB pada tahun 1971 dan kesepakatan Shanghai Communique pada tahun 1972 sebagai langkah menuju normalisasi hubungan bilateral AS dan China (Dahana, 2002a:170).

Melalui proses normalisasi hubungan dengan AS dan Barat, China semakin fokus untuk memulihkan ekonomi domestik. Maka, Deng Xiaopingpada tahun 1978 meluncurkan kebijakan reformasi ekonomi Four Modernizationsyangbertujuan untuk membuka ekonomi China kepada dunia (Abdul Razak Baginda, 2002:236). Sejak itu, China memacu perkembangan ekonominya serta membuka seluas-luasnya peluang kerjasama ekonomi dengan berbagai negara. Sampai kemudian berakhirnya Perang Dingin yang ditandai dengan runtuhnya Tembok Berlin pada tahun 1989 dan pecahnya Uni Soviet pada 1990.

\section{Hubungan Diplomatik dengan China}

Selepas memperoleh kedaulatannya sebagai sebuah negara merdeka dari Belanda pada tahun 1949 melalui perundingan Konferensi Meja Bundar (KMB), Indonesia mulai membuka diri dengan menjalin 
hubungan bilateral dengan berbagai negara. Bertolak dari prinsip politik luar negeri BebasAktif rumusan Moh. Hatta (Anak Agung Gde Agung, 1973:24), Indonesia memilih untuk segera mengakui dan menjalin hubungan diplomatik dengan RRC yang diresmikan pada tanggal 13 April 1950 (Artikel dalam www.deplu.go.id).

Langkah politik luar negeri tersebut menunjukan pendirian Indonesia untuk tidak memihak AS dengan Blok Barat-nya dan Uni Soviet dengan Blok Timur-nya serta pembuktian dari keaktifan Indonesia untuk terlibat dalam politik internasional yang diamanahkan Pancasila dan Undang-Undang Dasar (UUD) 1945 (Dewi Fortuna Anwar, 1994:18).Bagi Indonesia, hubungan diplomatikdengan Chinapenting untuk dua tujuan utama, yakni keluar dari cengkraman bipolarisme Perang Dingin serta memperkuat legitimasi kedaulatan Indonesia (Tuty Enoch Muas, 2009:26).Karenanya Indonesia memilih untuk membuka diri dengan kekuatankekuatan besar dunia yang berada di Blok Barat dan negara Non-Blok serta Blok Timur (Jon M. Reinhardt, 1973:43).

Sementara itu, Malaysia (masih bernama Federasi Malaya) yang baru merdeka dari Inggris pada 31 Agustus 1957 mengambil pilihan politik luar negeri yang berbeda dengan Indonesia. Sejak merdeka,Perdana Menteri (PM) Tunku Abdul Rahman mengikat Malaysia dengan Blok Barat melalui perjanjian Anglo-Malaya Defense Agreement (AMDA) tahun 1957 untuk mendapat perlindungan keamanan dari Inggris (Chamil Wariya, 1989:23).Kebijakan tersebut didorong oleh fakta bahwa kemerdekaan Malaysia yang dicapai ketika negara berada dalam situasi Darurat Nasional (1948-1960) menghadapi gerakan komunis PKMserta belum adanya tentara nasional yang menjaga keamanan negara(Dahana, 2002a:50).

Karena itu, Malaysia kemudian mengembangkan politik luar negeri yang anti komunis. Kebijakan ini terlihat dari permusuhan Malaysia kepada China yang dinilai sebagai pendukung gerakan pemberontakan komunis PKM yang mayoritas anggotanya merupakan etnis China Perantauan (Chandran Jeshurun, 2007:52).Malaysia bahkan tidak menjalin hubungan diplomatik dengan China (Dahana, 2002a:120) sampai dengan tahun 1974 ketika akhirnya kedua negara mau menjalin hubungan diplomatik (Johan Saravanamuttu, 2010:124).

Pilihan politik luar negeri Indonesia dan Malaysia terhadap China tersebut dapat dipahami dalam beberapa konteks. Bagi Indonesia yang segera menjalin hubungan diplomatik dengan China merupakan upaya untuk tidak masuk dalam peta konflik dua kuasa superpower dunia yang merupakan implementasi dari prinsip "Bebas-Aktif” (Rizal Sukma, 1999:23). Sementara dari konteks politik domestik, hubungan diplomatik dengan China mampu menjawab tuduhan bahwa politik luar negeri Indonesia pro-Barat. Meski demikian, hubungan diplomatik dengan China juga mendatangkan resiko baru bagi rezim 
penguasa, yakni resistensi dari kelompok politik Islam dan TNI (Tentara Nasional Indonesia) yang masih sangat sensitif dengan komunisme akibat pemberontakan PKI di Madiun tahun 1948.Hubungan diplomatik Indonesia-China juga mendatangkan keuntungan bagi China dalam upaya untuk mendapatkan dukungan politik dan ekonomi dari komunitas etnis China Perantauan yang berjumlah sangat banyak di Indonesia (Leo Suryadinata, 2009:122).

Sementara itu, kebijakan antagonis Malaysiadengan China hingga tahun 1974 didorong oleh beberapa faktor berikut, yaknikolonialisasi Inggris (asas pro-Barat), situasi Darurat Nasional (pemberontakan PKM) serta sikap dukungan China kepada PKM (Saravanamuttu, 2010:71). Selain itu, sikap pro-Barat Malaysia ini juga berkaitan erat dengan kepentingan ekonomi nasionalnya yang masih sangat bergantung kepada ekonomi Barat. Angka-angka berikut menunjukan ketergantungan tersebut, yakni; 70 persen perdagangan luar negeri Malaysia, 83 persen perusahaan getah dan 63 persen produksi timah masihditopang dan dimiliki oleh perusahaan Barat (Dahana, 2002a:120).

Adapun terkait dengan perubahan pilihan politik luar negeri Malaysia yang akhirnya menjalin hubungan diplomatik dengan China pada tahun 1974 dipengaruhi oleh berbagai faktor utama, seperti perkembangan situasi internasional yang menunjukan perubahan drastis sejak awal dekade 1970-an yang ditandai dengan proses normalisasi hubungan AS dan China.Namun demikian, beberapa faktor berikut dinilai lebih dominan mempengaruhi perubahan politik luar negeri Malaysia terhadap China, yaitu: pertama, terancamnyaMalaysia akibat keputusan Inggris untuk menarik mundur pasukannya dari wilayah-wilayah di sebelah timur Terusan Suez pada tahun 1971 seiring dengan berakhirnya politik konfrontasi antara Indonesia dan Malaysia serta terbentuknya ASEAN. Sebagai antisipasinya, Malaysia bersama Inggris membentuk FPDA (Five Power Defense Agreement) pada tahun 1971untuk menggantikan AMDA (Dahana, 2002a:172).Malaysia juga mulai merumuskan ulang arah politik luar negerinya, dari yang terlalu Pro-Barat menjadi lebih objektif. Hal ini tergambar dari bergabungnya Malaysia dengan kelompok negara Non-Blok sampai dengan mendorong realisasi konsep Zone of Peace, Freedom and Neutrality (ZOPFAN) di ASEAN pada tahun 1971(Saravanamuttu, 2010:121).

Kedua, permasalahan etnis China di Malaysia akibat peristiwa kerusuhan antara etnis China dengan Melayu pada 13 Mei 1969 setelah Pemilu 1969. Dampak dari peristiwa tersebut, koalisi pemerintah Barisan Nasional kehilangan dukungan dari mayoritas etnis China Malaysia. Untuk memulihkan dukungan bagi pemerintahan dari etnis China, Barisan Nasional berbenah. Salah satunya dengan peralihan kekuasaan dari PM Tunku Abdul Rahman kepada Wakil PM Tun Abdul Razak pada tahun 1970 (Saravanamuttu, 2010:173) 
Selain transisi kekuasaan, dukungan dari China dinilai penting untuk memulihkan dukungan etnis China terhadap pemerintah.

Kedua faktor tersebut yang akhirnya mendorong Malaysia untuk mulai menjajaki hubungan diplomatik dengan China. Beberapa langkah dilakukan, mulai dari mendukung China untuk menduduki kursi anggota tetap Dewan Keamanan PBB yang selama ini diduduki oleh Taiwan, mengirim misi kerjasama perdagangan ke China (Poon Kim Shee, 2004:60) hingga perundingan langsung kedua negara di PBB pada tahun 1973. Hasilnya,hubungan diplomatik kedua negara diresmikan pada 31 Mei 1974 (Saravanamuttu, 2010:124). Meski demikian, hubungan kedua negara tidak berkembang dengan baikhingga tahun 1980-an akibat masih adanya dukungan PKC kepada PKM(Dahana, 2002a:199).Bagi Malaysia, tanpa dihentikannya dukungan tersebut, upaya memberantas perlawanan PKM akan terus terhambat (Stephen Leong, 1987:1110).

\section{Politik Luar Negeri di Era Politik}

\section{Konfrontasi}

Sejak menjalin hubungan diplomatik, hubungan Indonesia dengan China tidak berkembang dengan akibat kekhawatiran akan pengaruh komunisme (Sukma, 1999:22). Hubungan kedua negara mulai menggeliat di era PMAli Sastroamidjojo pada tahun 1953. Sejak itu, beberapa kebijakan strategis diambil, seperti mengirim Duta Besar Indonesia ke China pada bulan Oktober 1953, meresmikan perjanjian perdagangan kedua negara pada bulan Desember 1953, menyelesaikan permasalahan status kewarganegaraan masyarakat China Perantauan di Indonesia melalui Perjanjian Kewarganegaraan Ganda (Dual Nationality)(Sukma, 1999:26) sampai dengan melibatkan China dalam Konferensi Asia Afrika (KAA) pada 18-24 April 1955 di Bandung.

Momen KAA merupakan salah satu pencapaian terbesar dalam sejarah politik luar negeri Indonesia. Melalui keikutsertaan China, legitimasi KAA sebagai suara bangsa-bangsa di Asia dan Afrikamenjadi semakin kuat. Selain itu, Indonesia juga berhasil memperjuangkan agenda kepentingan nasionalnya dengan mendapatkan dukungan dari peserta KAA terhadap kepemilikan Irian Barat dari penguasaan Belanda. Sementara bagi China, KAA digunakan untuk keluar dari politik pembendungan(containment policy) yang dilakukan oleh AS sekaligus mengikis stigma bahwa Chinaterlalu pro-Uni Soviet (Artikel dalamhttp://indonesian.cri.cn). Sejak KAA itulah hubungan Indonesia-China semakin mesra. Salah satunya ditandai dengan kunjungan kenegaraan Presiden Soekarno ke China pada 30 September 1956 (Hong Liu, 2009:50).

Seiring dengan peningkatan hubungan kedua negara, situasi domestik Indonesia mengalami guncangan hebat. Mulai dari gagalnya sistem Demokrasi Parlementer sampai dengan pemberontakan di berbagai daerah. Untuk mengendalikan situasi ini, Presiden Soekarno mengeluarkan Dekrit 5 Juli 
1959 yang membubarkan Konstituante (parlemen), membentuksendiri MPRS (Majelis Perwakilan Rakyat Sementara) dan DPAS (Dewan Pertimbangan Agung Sementara) serta memberlakukan kembali UUD 1945. Sejak itu, secara defacto dan dejure, Presiden Soekarno berkuasa secara penuh di Indonesia (Ganewati Wuryandani, 2008:92).

Era kekuasaan absolut Soekarno yang dinamakan Demokrasi Terpimpin ditopang oleh konsepsi nasional NASAKOM (Nasionalis, Agama, Komunis) yang menggabungkan tiga elemen sosial politik paling besar dan berpengaruh di Indonesia saat itu, yakni TNI, PKI dan kelompok Islam yang diwakili oleh Nahdlatul Ulama sebagai pendukung utama kekuasaannya. Pilihan Soekarno menggandeng PKI setidaknya didorong oleh dua faktor utama, yakni;pertama, kekecewaannya terhadap AS dan Barat karena turut mendukung berbagai pemberontakan di dalam negeri, seperti gerakan Pemerintahan Revolusioner Republik Indonesia (PRRI)/Perjuangan Rakyat Semesta (Permesta). Kedua, perlunya Soekarno akan dukungan dari partai politik terbesar di dalam negeri. Secara de facto, PKImasa itu adalah partai politik terbesar di Indonesiasetelah dibubarkannya Masyumi dan Partai Sosialis Indonesia (PSI). Faktor PKI ini juga dinilai memberi pengaruh besar dalam politik luar negeri Soekarno yang condong ke kiri dan radikal (Bradley R. Simson, 2008:44). Kedua faktor tersebut yang mempengaruhi pilihanpolitik luar negeri Soekarno yang radikal dan anti-Barat.

Kekecewaan Soekarnoterhadap Barat semakin besar akibat dukungan Barat kepada Belanda dalam kasus perebutan Irian Barat (Sukma, 1999:28). Pandangan anti Barat semakin terlihat nyata ketika Soekarno menolak pembentukan Federasi Malaysia pada tahun 1963 yang akan menggabungkan wilayah Malaya dengan daerah bekas jajahan Inggris lainnya, yakni Singapura, Sabah, Serawak dan Brunei. Baginya, pembentukan Malaysia merupakan kebijakan Barat untuk mengembalikan kolonialisme dan imperialismenya di Asia Tenggara serta bagian dari upaya Barat untuk mengepung Indonesia (Dahana, 2002a:125).

Adapun bagi PM Tunku Abdul Rahman, pembentukan Malaysia yang menggabungkan bekas koloni Inggris di Semenanjung Malaya dan di Borneo (Kalimantan) Utara didorong oleh dua faktor utama, yaitu; pertama, untuk menyeimbangkan posisi etnis dalam peta penduduk Malaya melalui penggabungan wilayah Borneo Utara yang banyak diisi oleh masyarakat asli atau bumiputera. Kedua,kekhawatiran akan jatuhnya Singapura ke tangan kekuatan prokomunis yang dinilai dapat memperkuat posisi pemberontak PKM (Dahana, 2002a:125).

Soekarno menutup mata terhadap berbagai alasan tersebut. Bahkan Soekarno melancarkan politik konfrontasi kepada Malaysia sebagai sikap perlawanannya kepada Barat. Untuk mendukung kebijakan tersebut, Soekarno mendekat kepada Uni Soviet. 
Namun, respon Uni Soviet mengecewakkan Soekarno (Wuryandani, 2008:106). Maka, Soekarno kemudian beralih ke China yang lebih memberikan respon positif atas politik konfrontasinya.Bagi China, dukungan kepada Indonesia juga didorong oleh beberapa kepentingannya, seperti untuk merebut simpati dari negara-negara dunia ketiga, memperkuat posisi tawar China di hadapan Uni Soviet,memperluas pengaruhnya di Asia (Simpson, 2008:125) serta melawan upaya Barat yang akan mendirikan benteng antikomunisme di Asia Tenggara melalui pembentukan Malaysia (Dahana, 2002a:125).

Melalui politik konfrontasi ini, hubungan Indonesia-China semakin solid dan saling mendukung. Jika Indonesia mendukung China untuk mengambil alih kursi anggota tetap DK PBB dari Taiwan maka China mendukung keputusan Indonesia untuk keluar dari keanggotaan PBB pada 7 Januari 1965 akibat kecewa atas terpilihnya Malaysia sebagai anggota tidak tetap DK PBB.Kedua negarakemudian membentuk poros JakartaBeijing pada bulan Agustus 1965 serta memulai kampanye perlawanan dengan memunculkan slogan New Emerging Forces sebagai anti-tesis dari Old Established Forcesyakni AS dan sekutunya (Sukma, 1999:32), mendirikan tandingan PBB yang dinamakan CONEFO (Conference of the New Emerging Forces) pada tahun 1965 sampai dengan menyelenggarakan GANEFO (Games of the New Emerging Forces) untuk menandingi Olimpiade (Dahana,
2002a:133).Namun demikian, kemesraan politik kedua negara harus berakhir seiring dengan terjadinya peristiwa Gerakan September 30 (Gestapu) pada tahun1965 di Indonesia (Michael Leifer, 1989).

\section{China sebagai Ancaman bagi Indonesia}

Terjadinya peristiwa Gestapu pada 1965 merubah konstelasi politik nasional di Indonesia. Soekarno dan Orde Lama harus tersingkir dari kursi kekuasaan di Indonesia akibat komplikasi peristiwa Gestapu yang dikaitkan dengan hubungan Soekarno dengan PKI dan China. PKI menjadi tertuduh utama dari,sedangkan China disebut sebagai pendukung PKI. Gestapu menjadi momen bagi Angkatan Darat (AD) TNI untuk membubarkan PKIsekaligus memecah hubungan mesra Soekarno dengan China.

Menurut Soeharto dan AD TNI, keterlibatan China dalam Gestapu diindikasikan dari kunjungan DN Aidit selaku pimpinan PKI ke China untuk bertemu dengan pimpinan PKC pada bulan Agustus 1965, pertemuan antara pimpinan China dengan Panglima Angkatan Udara TNI Oemar Dani pada bulan September 1965 (Muas, 2009:31), ditemukannya kiriman senjata dari China untuk PKI pada tahun 1965 yang diselundupkan dengan dalih untuk keperluan pelaksanaan CONEFO (Artikel dalam Majalah Tempo, 6 Oktober 1990).

China menolak tuduhan keterlibatannya atas peristiwa Gestapu. China bahkan mengambil sikap yang sangat keras atas 
tuduhan Soeharto dan AD TNI, mulai dari menyebut AD TNI sebagai antek Barat sampai menghentikan bantuan ekonomi kepada Indonesia. Sikap keras China ini akhirnya memunculkan protes dan sentimen negatif dari sebagain besar masyarakat Indonesia. Benny G. Setiono dalam Tionghoa dalam Pusaran Politik (2002) menyebutkan berbagai kampanyeanti China dan anti etnis China (Tionghoa) terjadi dibanyak wilayah. Mulai dari penyerangan terhadap kantor-kantor Konsulat China sampai dengan penyerbuan kantor Konsulat Jenderal China di Jakarta pada 24 Maret 1966. Puncaknya adalah penyerbuan dan perusakan terhadap gedung Kedutaan Besar China di Jakarta pada 1 Oktober 1967. Berdasarkan berbagai hal tersebut, Soeharto sebagai Pelaksana Tugas Presiden (Acting President) mengambil kebijakan tegas, yakni membekukan hubungan diplomatik Indonesia dengan Chinapada 9 Oktober 1967 (Sukma, 1999:34).

Pembekuan hubungan diplomatik tersebut setidaknya didorong oleh dua faktor berikut, yaitu pertama, untuk menghindarkan Indonesia dari potensi jatuh ke tangan komunisme.Kedua, tindakan keras Soeharto terhadap PKI dan China dijadikan sebagai dasar legitimasi kekuasaan rezim Orde Baru yang didirikannya.Sejak itu, China dipersepsikan sebagai ancaman bagi Indonesia yang didasari oleh tiga faktor utama, yakni;pertama, kecurigaan mengenai loyalitas masyarakat etnis China (Tionghoa) di Indonesia yang diyakini memiliki keterkaitan dengan PKI dan RRC. Kedua, sejarah China yang selalu turut campur dalam setiap masalah yang berkaitan dengan etnis China di Indonesia. Ketiga, gabungan dari kedua faktor tersebut yang kemudian menjadi dasar bagi legitimasi kekuasaan Orde Baru (Sukma, 1999a:143).

\section{Pemulihan Hubungan Diplomatik Indonesia dengan China}

Pembekuan hubungan diplomatik kedua negara menimbulkan sejumlah masalah bagi peranan politik luar negeri Indonesia, terutamanya untuk dapat berperan aktif di politik internasional. Salah satu efek yang dirasakan Indonesia adalah ketika Indonesia ingin menjadi Ketua Gerakan Non-Blok yang tentunya memerlukan dukungan dari China selaku kekuatan besar yang berpengaruh di Asia (Muas, 2009:35). Akibat pembekuan hubungan diplomatik, maka peluang komunikasi dan dukungan China menjadi tertutup.

Sementara itu, dalam konteks politik domestik, juga berkembang tuntutan untuk memulihkan hubungan diplomatik dengan China. Meski kemudian masih terganjal dengan beberapa permasalahan seperti masalah status warganegara China Perantauan, yang akhirnya diselesaikan melalui Instruksi Presiden No. 2/1980 dan Ketetapan Presiden No. 13/1980. Ganjalan lain adalah masih kuatnya kecurigaan akan dukungan China kepada komunisme di Asia Tenggara (Artikel dalam Majalah Tempo, 29 Maret 1980). 
Selain dari pihak Indonesia, dorongan untuk memulihkan hubungan diplomatik juga bergulir di China. Bahkan China sampai mengeluarkan pernyataan resmi untuk menegaskan sikapnya terhadap komunis di Indonesia, yakni baik Pemerintah China atau PKC secara tegas tidak mendukung perjuangan pihak komunis di Indonesia serta tidak pernah terlibat dalam peristiwa Gestapu tahun 1965 (Muas, 2009:35).

Menyikapi beberapa perkembangan internasional dan domestik tersebut, Indonesia kemudian memutuskan untuk memulihkan kembali hubungan diplomatik dengan China yang terputus selama 23 tahun pada 8 Agustus 1990 (Muas, 2009:129). Sebagai konsekuensi pemulihan hubungan tersebut, Indonesia kemudian menganut kebijakan One China Policy dengan tidak mengakui Taiwan sebagai sebuah negara (Ian James Storey, 2000).

\section{Malaysia dan China dalam Konflik Laut China Selatan}

Konflik perebutan klaim kepemilikan Kepulauan Paracel dan Spratly di Laut China Selatan melibatkan China, Malaysia, Vietnam, Brunei dan Filipina. Malaysia mulai terlibat melalui kebijakan memasukan beberapa wilayah dari Kepulauan Spratly dalam Peta Baru Nasional pada tahun 1979. Tindakan Malaysia tersebut direspon keras oleh China yang menilai hal tersebut sebagai intervensi terhadap kedaulatannya (Baginda, 2002:237). Malaysia tidak mengindahkan berbagai protes tersebut dikarenakan menilai wilayah tersebut berstatus sengketa internasional. Bahkan
Malaysiamengambil tindakan agresif dengan menguasai Terumbu Layang-Layang pada bulan Juni 1983. Meski kembali diprotes oleh China dan Vietnam, Malaysia tidak bergeming (Leong, 1987:1115). Sengketa klaim Spratlyini memang sempat menimbulkan gangguan dalam hubungan Malaysia-China. Namun, gangguan lain yang lebih dirasakan oleh Malaysia adalah masih adanya dukungan PKC kepada PKM(Leong, 1987:1117). Namun demikian, hubungan selama 10 tahun (19741984) kedua negara secara umum berjalan dengan baik di era kepemimpinan PM Mahathir.

\section{Kerjasama Ekonomi}

Jatuhnya harga minyak di dunia pada awal 1980-an sangat mempengaruhi ekonomi nasional Indonesia dikarenakan 60 persen penerimaan keuangan negara berasal dari sektor minyak (Suryadinata, 1990a:687). Berbagai upaya dan terobosan dilakukan, termasuk dengan aktif membuka pasar ekonomi negara-negara Eropa Timur. Meski tidak memiliki hubungan diplomatik, China juga masuk dalam fokus pasar ekonomi Indonesia sebagai usaha untuk keluar dari situasi negatif ini (Artikel dalam Majalah Tempo, 13 Juli 1985).Terlebih China telah menunjukan perkembangan ekonomi yang signifikan pasca kebijakan modernisasinya di tahun 1978.

Indonesia memulai penjajakan kerjasama ekonominya dengan China melalui perantaraan kelompok pengusaha dari Kamar Dagang Indonesia (KADIN) pada November 
1977 (Muas, 2009:33). Seiring dengan perkembangan hubungan dagang yang meningkat, kedua negara menjalin hubungan dagang resmi melalui Memorandum of Understanding (MoU) pada 5 Juli 1985 (Artikel dalam Majalah Tempo, 13 Juli 1985).Sejak itu, transkasi perdagangan meningkat drastis. Tahun 1982-1985, jumlah transaksi perdagangan kedua negara hanya senilai US\$ 230 pertahunnya. Sejak tahun 1985 sampai 1988, jumlahnya meningkat lebih dari dua kali lipat, menjadi US\$ 500 pertahunnya (Hasjim Djalal, 1997:88).

Sementara itu, Malaysia telah menempatkan hubungan dengan China sebagai fokus kerjasama ekonomi internasionalnya. PM Mahathir (2011:431-432) menyadari China sedang berkembang dan akan segera menjadi kekuatan besar ekonomi dunia. Karenanya Malaysia akan lebih fokus pada keuntungan ekonomi yang didapatkan dalam hubungannya dengan China (Wawancara penulis dengan Mahathir). Dalam kunjungan resmi pertamanya ke China pada bulan November 1985, Mahathir menegaskan pandangan tersebut dengan pernyataannya: "we must now put 'economics in command'!'(Leong, 1987:1122).

Melalui pendekatan ekonomi, hubungan kedua negara berkembang pesat. Perdagangan kedua negara meningkat drastis dari senilai US\$ 289 juta di tahun 1981 menjadi US\$ 557 juta di tahun 1987. Jumlah ini terus meningkat di tahun 1988 yang mencapai US\$ 877 juta sampai kemudian mencapai jumlahnya yang sangat siginifikan di tahun 1990 yaitu US\$ 1183 juta (Kim Shee, 2004:39). Peningkatan hubungan kedua negara juga turut didorong oleh hilangnya salah satu ganjalan utama yang ada selama ini, yakni perlawanan PKM yang berakhir pada tahun 1989 (Cheng Chwee, 2010a:50).

Pendekatan ekonomi menjadi pilihan bagi Indonesia dan Malaysia di era Perang Dingin sebagai respon terhadap mulai terlibatnya China dalam politik internasional. Bagi Indonesia, diplomasi ekonomi dengan China menjadi pilot project untuk memulai kembali hubungan kedua negara.Sementara pilihan pendekatan kerjasama ekonomi yang diambil Malaysia terhadap China menjadi tanda yang siginifikan akan kuatnya persepsi peluang ekonomi dari China. Faktor inilah yang akhirnya mengesampingkan pengaruh ideologi dalam kebijakan ekonomi Malaysia di era PM Mahathir.

\section{Kesimpulan}

Berdasarkan pembahasan dalam kajian ini, struktur internasional bukanlah faktor dominan yang mempengaruhi pilihan politik luar negeri Indonesia dan Malaysia terhadap China. Struktur internasional memang menjadi salah satu faktor yang memberikan tekanan kepada negara untuk merespon. Namun demikian, pilihan respon yang diambil oleh negara tersebut, sepenuhnya tergantung pada faktor domestik yang menerjemahkan tekanan tersebut. Perbedaan dalam penerjemahan inilah yang melahirkan pilihan politik luar negeri Indonesia dan Malaysia terhadap China. 
Nabil Ahmad Fauzii 
Tabel 2

\begin{tabular}{|c|c|c|}
\hline $\begin{array}{c}\text { Independent } \\
\text { Variable } \\
\text { (Struktur } \\
\text { Internasional) }\end{array}$ & $\begin{array}{c}\text { Intervening Variables } \\
\text { (Faktor Domestik) }\end{array}$ & $\begin{array}{c}\text { Dependent Variable } \\
\text { (Pilihan Politik Luar } \\
\text { Negeri) }\end{array}$ \\
\hline $\begin{array}{l}\text { Perubahan Sistem } \\
\text { Kekuatan } \\
\text { Internasional: } \\
\text { - Perang Dingin } \\
\text { (bipolarisme) } \\
\text { - Politik Segitiga } \\
\text { (AS, Uni } \\
\text { Soviet dan } \\
\text { China) }\end{array}$ & $\begin{array}{l}\text { Kepentingan Rezim, Persepsi } \\
\text { Pemimpin dan Persepsi } \\
\text { Ancaman: } \\
\text { Indonesia: } \\
\text { - Pergantian rezim } \\
\text { (Orde Lama-Orde Baru } \\
\text { - Legitimasi Rezim Orde } \\
\text { Baru } \\
\text { - Perubahan persepsi } \\
\text { pemimpin dan elite } \\
\text { Malaysia: } \\
\text { - Pergantian pemimpin } \\
\text { negara } \\
\text { (Tunku Abdul Rahman-Tun } \\
\text { Abdul Razak- Mahathir) } \\
\text { Perubahan persepsi } \\
\text { pemimpin dan elite } \\
\text { (persepsi kepentingan } \\
\text { ekonomi) }\end{array}$ & $\begin{array}{l}\text { Persamaan dan } \\
\text { perbedaan Politik } \\
\text { luar negeri } \\
\text { Indonesia } \\
\text { terhadapChina } \\
\text { - Poros Jakarta- } \\
\text { Beijing } \\
\text { - China sebagai } \\
\text { ancaman } \\
\text { nasional. } \\
\text { - Kerjasama } \\
\text { Ekonomi } \\
\text { Malaysia } \\
\text { terhadapChina : } \\
\text { - China sebagai } \\
\text { ancaman } \\
\text { nasional. } \\
\text { - Hubungan } \\
\text { diplomatik dan } \\
\text { - Hubungan erat } \\
\text { Ekonomi }\end{array}$ \\
\hline
\end{tabular}




\section{Daftar Pustaka}

Abdullah Dahana. China's Role in Indonesia's “Crush Malaysia” Campaign. Jurnal Makara-Sosial Humaniora. 6(2). 2002.

Abdullah Dahana. China dan Malaysia dalam A rena Perang Dingin 1949-74. Bangi: Penerbit UKM. 2002.

Abdul Razak Baginda. Malaysian Perceptions of China: From Hostility to Cordiality, dalam Yee, Herberts dan Ian Storey. The China Threat: Perceptions, Myths and Reality. London: RoutledgeCurzon. 2002.

Alagappa,Muthiah. ed. Political Legitimacy in Southeast Asia: The Quest for Moral Authority. Stanford: Stanford University Press. 1995.

Anak Agung Gde Agung. Twenty Years Indonesian Foreign Policy1945-1965. The Hague: Mouton. 1973.

Azar, Edward E. and Chung-In Moon, eds. National Security in the Third World: The Management of Internal and External Threats. Hants, England: Edward Elgar. 1988.

Beetham, David . The Legitimation of Power. London: MacMillan. 1991.

Benny G. Setiono. Tionghoa dana Pusaran Politik. Jakarta: ELKASA. 2002.

Chamil Wariya. Politik Luar Negeri Era Mahathir. Kuala Lumpur: Penerbit Fajar Bakti. 1989.

Choplin, William D. Pengantar Politik Internasional: Suatu Telaah Teoritis. Bandung: Sinar Baru. 1992.

Chwee, Kuik Cheng. Analyzing Malaysia's Changing Alignment Choices 1971-1989. Jurnal Jebat FSSK Universiti Kebangsaan Malaysia. 37. 2010.

.Malaysia's China Policy in the Post-Mahathir Era: A Neoclassical Realist Explanation. RSIS (S. Rajaratnam School of International Studies) Working Paper No. 244 (30 Juli). 2012.

Dewi Fortuna Anwar. Indonesia in ASEAN: Foreign Policy and Regionalism. Singapore: ISEAS. 1994.

Ganewati Wuryandani. Politik Luar Negeri Indonesia Era Orde Lama, dalam Ganewati Wuryandani (Ed). Politik Luar Negeri Indonesia di Tengah Pusaran Politik Domestik. Jakarta: P2P-LIPI-Pustaka Pelajar. 2008.

Hasjim Djalal. Politik Luar Negeri Indonesia dalam Dasawarsa 1990. Jakarta: CSIS. 1997.

Holsti, K.J. Politik Internasional: Kerangka Untuk Analisis. (terj.). Jilid I Edisi ke-4. Jakarta: Erlangga. 1998.

I. Wibowo dan Syamsul Hadi (Ed). Merangkul China: Hubungan Indonesia-China Pasca Soeharto. Jakarta: PT. Gramedia Pustaka Utama. 2009.

Jervis, Robert. Perception and Misperception in International Politics. New Jersey: Princeton University Press. 1976.

Jeshurun, Chandran. Malaysia: Fifty Years of Diplomacy 1957-2007. Kuala Lumpur: The Other 
Press. 2007.

Jones, Walter S. Logika Hubungan Internasional Persepsi Nasional. Jilid I. Jakarta: Gramedia Pustaka Utama. 1988.

Leo Suryadinata.”Indonesia-China Relations: A Recent Breakthrough,“'Asian Survey 30 (7) (July). 1990

Overseas Chinese in Southeast Asia and China's Foreign Policy, dalam Geoff Wade (Ed). China and Southeast A sia. Oxon: Routledge Library on Southeast Asia. 2009.

Leifer, Michael. ASEAN and the Security of Southeast A sia. London: Routledge. 1989.

Leong, Stephen. Malaysia and the People's Republic of China in the 1980s: Political Vigilance and Economic. A sian Survey. 27 (10). 1987.

Liu, Hong. Constructing A China Metaphor: Sukarno's Perception of the RRC and Indonesia's Political Transformation, dalam Geoff Wade (Ed). China and Southeast Asia. Oxon: Routledge Library on Southeast Asia. 2009.

Mahathir Muhammad. A Doctor in the House: The Memoirs of Tun Dr. Mahathir Mohama. Kuala Lumpur: MPH. 2011.

Paribatra, Sukhumbhand and Chai-Anan Samudavanija."Internal Dimensions of Regional Security in Southeast Asia,"dalam Mohammed Ayoob, ed., Regional Security in the Third World, Boulder, CO: Westview. 1986.

Rizal Sukma. Indonesia and China: The Politics of a Troubled Relationship. London: Routledge. 1999.

"Masalah Cina" dalam Kerangka Hubungan Indonesia-RRC, dalam I. Wibowo, (ed), Retrospeksi dan Rekontekstualisasi Masalah Cina. Jakarta: PT. Gramedia Pustaka. 1999.

Reinhardt, Jon M. Foreign Policy and National Integration: The Case of Indonesia. Connecticut: Yale University Southeast Asia Studies. 1971.

Rose, Gideon. Neoclassical Realism and Theories of Foreign Policy. World Politics. 51(1). 1998.

Saravanamuttu, Johan. Malaysia's Foreign Policy the First fifty Years: Alignment, Neutralism and Islamism. Singapore: ISEAS. 2010.

Shee, Poon Kim. The Political Economy of Mahathir's China Policy: Economic Cooperation, Political and Strategic Ambivalence. Ritsumeikan Annual Review of International Studies 2004, 3 .

Storey, Ian James. "Indonesia's China Policy in thr New Orderr and Beyond: Problems and Prospects", Contemporary Southeast Asia, (April). Lihat web: http://findarticles.com/p/ articles. 2000.

Soeharto: Biografi Singkat 1921-2008. Yogyakarta: Garasi. 2009.

Tuty Enoch Muas. Hubungan Indonesia-China: Secara Historis, Dinamis!, dalam I. Wibowo dan Syamsul Hadi (Ed). Merangkul China: Hubungan Indonesia-China Pasca Soeharto. Jakarta: PT. Gramedia Pustaka Utama. 2009.

Tilman, Robert O. Southeast Asia and The Enemy Beyond: ASEAN Perceptions of External Threats. London: Westview. 1987. 
Weber, Max. "Legitimacy, Politics, and the State," dalam William Connolly, ed., Legitimacy and the State. (New York: New York University Press. 1984.

Wriggins, Howard. The Ruler's Imperative: Strategies for Political Survival in Asia and Africa. New York: Columbia University Press. 1969.

\section{Sumber Internet:}

"Bilateral Cooperation Indonesia and China." Lihat web:

http://www.deplu.go.id/Pages/ $\underline{\text { IFPDisplay.aspx }}$ Name $=$ BilateralCooperation $\& I D P=58 \& \mathrm{P}=$ Bilateral\&l $=\mathrm{en}$

"Berdagang Sampai ke Negeri China" Majalah Tempo (13 Julai 1985). http:// majalahal.tempointeraktif.com/id/arsip/1985/07/13/NAS/ mbm.19850713.NAS37101.id.html.

'Mao Zedong proclaims People's Republic of China', Lihat Web: http://www.history.com/this-day -in-history/mao-zedong-proclaims-peoples-republic-of-china.

Kementerian Luar Negeri Indonesia,Lihat web : http://www.kemlu.go.id/Pages/IFPDisplay.aspx? $\underline{\text { Name }=\text { BilateralCooperation } \& I D P=58 \& P=B i l a t e r a l \& l=i d}$

"Pilihan Wajar Sejarah: Konferensi Bandung 1955," Lihat web: http:// indonesian.cri.cn/1/2005/04/12/1@27402.htm.

“China Terlibat atau Tidak?”, Majalah Tempo (6 Oktober 1990). http: //ip52-214.cbn.net.id/id/ arsip/1990/10/06/NAS/mbm.19901006.NAS19592.id.html.

"Es itu Mencair Pelan-pelan", Majalah Tempo (29 Maret 1980).http: // majalahal.tempointeraktif.com/id/arsip/1980/03/29/NAS/ mbm.19800329.NAS51906.id.html. 